\title{
BREAD FRUITS PUDDING DENGAN PEMANIS ALAMI SEBAGAI ALTERNATIF DESSERT UNTUK PASIEN DIABETES MELLITUS
}

\author{
(Bread Fruits Pudding With Natural Sweeteners as An Alternative Dessert For \\ Diabetes Mellitus Patients)
}

\author{
Rosyda Dianah ${ }^{1}$, Rayhan $^{1}$ \\ ${ }^{1}$ Sekolah Vokasi, Institut Pertanian Bogor, Jl Kumbang No. 14 Bogor Tengah \\ E-mail : rosydadianah@apps.ipb.ac.id
}

Diterima 27 Juni 2021/Disetujui 5 Agustus 2021

\begin{abstract}
The aim of this study is modify dessert for patients or people with diabetes mellitus in the form of Bread Fruit Pudding with natural sweeteners. Bread Fruit Pudding products use the main ingredients of jelly and low fat milk and fruit as a sweet taste. Pudding product development into bread fruit pudding is attempted to increase public insight regarding the importance of considering the use of sugar and changing the negative stigma of society regarding the consumption of fruit with a sweet taste. The production stage of Bread Fruits Pudding products consists of the preparation of materials and tools, the processing stage using the boiling technique $\left(100^{\circ} \mathrm{C}\right)$ and serving (150 grams/serving). The nutritional content of Bread Fruits Pudding is 92.7 Calories of energy; 5.3 grams of protein; 3.8 grams of fat; 12.9 grams of carbohydrates; 2.2 grams of fiber and 6.6 grams of natural sugar. The result of the preference test obtained that $78 \%$ liked the appearance and portion of the product, 56\% liked the taste and $89 \%$ liked the texture. The composition of ingredients in pudding products in the community generally uses a lot of sugar or added artificial sweeteners that increase the risk of Diabetes Mellitus, Pudding product development into bread fruit pudding is efforts are made to become a solution for pudding products that are safe for consumption without any risk to health in consuming it.
\end{abstract}

Key words : Dessert, Diabetes Mellitus, Natural Sweeteners, Pudding

\section{PENDAHULUAN}

Hidangan penutup (dessert) adalah hidangan yang disajikan paling akhir dalam sajian makanan dan biasanya mempunyai rasa manis serta menyegarkan, walau terkadang ada yang berasa asin atau kombinasinya. Dessert dengan cita rasa manis digemari oleh seluruh lapisan masyarakat. Jenis hidangan dessert sangat beragam, salah satunya adalah pudding manis terbuat dari agar-agar, tetapi ada jenis pudding yang bukan terbuat dari agar-agar, yaitu dari telur dan atau tepung pati. Pudding dikategorikan menjadi empat yaitu pudding agar-agar, starch thickened, baked puddings, dan steamed pudding (Ekawatiningsih, et.al. 2008). 
Produk pudding manis menggunakan gula dalam jumlah cukup banyak atau menggunakan bahan pemanis sebagai bahan tambahan. Pemanis termasuk ke dalam golongan bahan tambahan pangan buatan selain bahanbahan lainnya seperti antioksidan, pemutih, pengawet, pewarna, dan sebagainya. Pada dasarnya pemanis buatan (artificial sweeteners) merupakan senyawa yang secara substansial memiliki tingkat kemanisan lebih tinggi, yaitu berkisar antara 30 sampai dengan ribuan kali lebih manis dibandingkan sukrosa. Penggunaan pemanis buatan perlu diwaspadai karena dalam takaran yang berlebih dapat menimbulkan efek samping yang merugikan kesehatan manusia (Indrie 2009).

Efek samping dari pemakaian gula dalam jumlah banyak dan pemanis tambahan dapat berisiko terjadinya penyakit diabetes millitus. Menurut WHO (2000), diabetes melitus (DM) adalah suatu penyakit atau gangguan metabolisme kronis dengan multietiologi yang ditandai dengan tingginya kadar gula darah disertai dengan gangguan metabolisme karbohidrat, lipid dan protein sebagai akibat insufisiensi fungsi insulin. Pengembangan produk pudding dilakukan untuk menciptakan alternatif dessert dengan risiko rendah terjadinya penyakit diabetes mellitus dengan cara mengganti gula ataupun pemanis buatan dengan pemanis alami seperti buah-buahan yang indek glikemiknya rendah. Indeks glikemik (IG) merupakan suatu ukuran yang dikembangkan untuk mengklasifikasikan pangan berkarbohidrat berdasarkan pengaruh fisiologisnya terhadap kadar glukosa darah (Jenkins 1981).

Pengembangan produk pudding menjadi Bread Fruits Pudding menggunakan buah dengan kadar indeks glikemi yang rendah karena pangan ber-IG rendah diantaranya memiliki karakteristik yang dapat menyebabkan proses pencernaan di dalam perut berjalan lambat, sehingga laju pengosongan perut (gastric emptying rate) pun berlangsung lambat. Hal ini mengakibatkan suspensi pangan yang telah mengalami pencernaan di perut (chyme) lebih lambat mencapai usus kecil, sehingga pencernaan karbohidrat lebih lanjut dan penyerapan glukosa di usus kecil terjadi secara lambat. Pangan ber-IG rendah, sebagian besar penyerapan glukosa terjadi di usus kecil bagian atas (duodenum) dan bagian tengah (jejunum), pada akhirnya fluktuasi kadar glukosa darah pun relatif kecil yang ditunjukkan dengan landainya kurva respon glikemik. Karakteristik metabolik pangan ber-IG rendah ini dapat mengurangi respon glikemik dan insulin sehingga secara keseluruhan dapat memperbaiki kadar glukosa dan lemak darah, baik pada pasien diabetes mellitus (Brand 1991).

Penggunaan komposisi bahan pada produk pudding di kalangan masyarakat pada umumnya menggunakan gula dalam jumlah cukup banyak ataupun tambahan pemanis buatan yang dapat menimbulkan risiko penyakit diabetes milletus, sehingga dengan pengembangan produk ini diupayakan menjadi solusi bagi produk pudding untuk aman dikondumsi tanpa ada risiko bagi kesehatan dalam mengkonsumsinya sehingga penelitian ini bertujuan memodifikasi hidangan penutup untuk pasien ataupun orang-orang yang menderita diabetes mellitus berupa Bread Fruit Pudding dengan pemanis alami. 


\section{METODE PENELITIAN}

Penelitian ini dilakukan dengan melewati beberapa tahap yaitu penentuan dan pengembangan ide, uji coba produk berdasarkan resep dasar bread pudding, produksi produk, uji organoleptik dan finalisasi produk. Adapun alasan pemilihan produk ini diharapkan mampu menjadi pilihan menu selingan dan menambah variasi pengolahan pudding yang mengandung gizi cukup untuk pasien diabetes mellitus serta sehat dan aman untuk semua orang.

Produksi dan pengujian produk bread fruits pudding dilakukan sebanyak 8 kali uji coba. Uji coba ke-8 menghasilkan produk yang siap untuk diujikan kepada panelis. Jumlah panelis yang akan melakukan uji organoleptik produk sebanyak 36 orang terdiri dari masyarakat umum, pasien, dan tenaga pengolah makanan di rumah sakit.

Mekanisme uji organoleptik dilakukan dengan cara mendatangi panelis dengan membawa produk yang akan dinilai serta form penilaian uji organoleptik produk. Contoh produk atau sampel diberi kode sampel dan panelis menilai sesuai dengan cita rasa mereka. Panelis sebelumya diberitahukan bahwa produk yang akan diuji adalah salah satu jenis pudding. Format penilaian terhadap produk terdiri dari beberapa kategori penilaian yaitu penampilan, rasa, tekstur, dan porsi. Penilaian menggunakan skala angka meliputi 1 (sangat suka), 2 (suka), 3 (kurang suka) dan 4 (tidak suka). Hasil penilaian uji organoleptik akan diolah dengan program komputer sehingga diketahui daya terima terhadap produk dan perbaikan atau penyesuaian yang harus dilakukan agar produk dapat diterima oleh sasaran utama produk ini yaitu pasien diabetes serta dapat juga dikonsumsi olah semua masyarakat.

\section{HASIL DAN PEMBAHASAN}

Pengembangan produk merupakan serangkaian aktivitas yang dimulai dari analisis persepsi dan peluang pasar, kemudian diakhiri dengan tahap produksi, penjualan, dan pengiriman produk (Ulrich dan Steven 2001), sedangkan menurut Kotler dan Armstrong (2009), pengembangan produk adalah mengembangkan konsep produk menjadi produk nyata untuk dapat memastikan bahwa ide produk dapat di ubah menjadi produk yang bisa dikerjakan.

Salah satu cara pengembangan produk diantaranya modifikasi produk yang merupakan cara memperbaiki produk yang sudah ada meliputi kualitas, fitur dan style dengan tujuan meningkatkan penjualan. Modifikasi produk menciptakan tiga dimensi, yaitu perbaikan mutu (quality improvement), perbaikan ciri-ciri khas (feature Improvement) dan perbaikan gaya (style improvement). Modifikasi produk Bread fruits pudding menggunakan pemanis alami dari buah-buahan dan roti gandum yang tinggi serat sehingga baik dikonsumsi jangka panjang oleh masyarakat sebagai upaya mencegah diabetes mellitus ataupun alternatif dessert sehat bagi penderita diabetes mellitus. Produk Bread Fruits Pudding juga menggunakan buah dengan kadar indeks glikemi rendah seperti pisang, strawberry, jeruk, dan apel. 
Menurut Arif. Et.al (2013), pangan ber-IG rendah memiliki karakteristik yang dapat menyebabkan proses pencernaan di dalam perut berjalan lambat, sehingga laju pengosongan perut (gastric emptying rate) pun berlangsung lambat. Hal ini mengakibatkan suspensi pangan yang telah mengalami pencernaan di perut (chyme) lebih lambat mencapai usus kecil, sehingga pencernaan karbohidrat lebih lanjut dan penyerapan glukosa di usus kecil terjadi secara lambat. Fluktuasi kadar glukosa darah pada akhirnya relatif kecil yang ditunjukkan dengan landainya kurva respon glikemik, hal ini dapat mengurangi respon glikemik dan insulin sehingga secara keseluruhan dapat memperbaiki kadar glukosa dan lemak darah, baik pada pasien diabetes mellitus maupun pada orang sehat.

\section{Hidangan Pudding}

Pudding merupakan salah satu hidangan penutup yang umumnya dimasak dengan teknik boiling berbahan dasar agar-agar dan memiliki cita rasa yang manis dengan tekstur yang lembut sehingga di sukai oleh semua kalangan. Bahan tambahan dalam pembuatan puding beraneka macam mulai dari buah hingga sayuran, terdapat beberapa penelitian tentang puding yaitu "Kadar Antioksidan dan Uji Organoleptik Puding Kulit Buah Manggis dengan Penambahan Buah Kurma sebagai Perasa Manis Alami" (Arini 2015) dan "Pembuatan Puding Waluh (Cucurbita Moschata) dengan Pemanis Alami Daun Stevia (Stevia Rebaudiana) untuk Kudapan Penderita Diabetes" (Sari 2014).

Pudding dikategorikan menjadi 4 yaitu pudding agar-agar, starch Thickened, baked puddings dan steamed pudding. Pudding agar-agar terbuat dari agar-agar dan disajikan dingin. Starch Thickened atau boilled puddings menggunakan bahan pati jagung yang membutuhkan proses perebusan agar dapat mematangkan pati dan membuat pati menjadi kental. Baked pudding menggunakan teknik olah baking (panggang) atau au bain marie dengan bantuan oven. Steamed pudding menggunakan teknik kukus, bertekstur sangat berat dan penuh dengan isi dan disajikan hangat.

\section{Pemanis Dari Buah}

Buah merupakan pangan penting yang dapat menjadi sumber karbohidrat, vitamin, mineral, serat, dan senyawa fenolat yang berfungsi sebagai antioksidan. Sejumlah studi epidemiologi menunjukkan bahwa tingginya konsumsi buah berkorelasi negatif dengan risiko penyakit-penyakit kardiovaskular, kanker dan kronis seperti obesitas dan diabetes. Peningkatan konsumsi buah telah menjadi strategi dan prioritas global dalam memperbaiki tingkat kesehatan masyarakat (Ikram, et.al. 2009).

Buah direkomendasikan menjadi komponen penting dalam setiap jenis diet tetapi buah juga dapat mengandung gula sederhana yang cukup tinggi dan buah merupakan bagian yang tidak terpisahkan dari diet sehat dan telah menjadi pangan alternatif utama, khususnya pada orang-orang yang memerlukan pengaturan pola asupan karbohidrat pangan (dietary carbohydrates). Pemahaman mengenai indeks glikemik dari ragam buah yang ada sangat 
penting dalam pengendalian respon glikemik dan optimalisasi sifat fungsional karbohidrat dan senyawa fitokimia lain yang dikandungnya (Emanath 2011).

Pangan ber-IG rendah diantaranya memiliki karakteristik yang dapat menyebabkan proses pencernaan di dalam perut berjalan lambat, sehingga laju pengosongan perut (gastric emptying rate) pun berlangsung lambat. Hal ini mengakibatkan suspensi pangan yang telah mengalami pencernaan di perut (chyme) lebih lambat mencapai usus kecil, sehingga pencernaan karbohidrat lebih lanjut dan penyerapan glukosa di usus kecil terjadi secara lambat. Karakteristik metabolik pangan ber-IG rendah ini dapat mengurangi respon glikemik dan insulin, sehingga secara keseluruhan dapat memperbaiki kadar glukosa dan lemak darah, baik pada pasien diabetes milletus, maupun pada orang sehat ( Brand 1991). Proses sebaliknya terjadi pada pangan ber-IG tinggi dimana laju pengosongan perut, pencernaan karbohidrat dan penyerapan glukosa berlangsung cepat, sebagian besar penyerapan glukosa hanya terjadi di usus kecil bagian atas sehingga kurva respon glikemik dicirikan dengan tingginya fluktuasi kadar glukosa darah.

Buah dengan IG-rendah dapat dijadikan sebagai pemanis alami yang aman dikonsumsi oleh penderita penyakit degeneratif seperti diabetes mellitus (Jenkins, et.al. 2002). Produk pengembangan dari pudding ini yakni bread fruits pudding yang dalam produksinya menggunakan buah dengan kadar IG-rendah. Jumlah buah yang dipakai memang tidak banyak karena fungsinya sebagai pengganti fungsi gula untuk pemberi rasa manis pada pudding. Anjuran Kemenkes (2014) yang terdapat dalam pesan umum gizi seimbang berupa konsumsi buah sebanyak 3-5 porsi sehari dapat dipenuhi dengan menambah konsumsi buah sesuai dengan anjuran.

\section{Bread Fruits Pudding}

Pengembangan produk pudding dilakukan untuk memperbaiki kandungan kadar gula dan serat hidangan pudding. Produk Bread Fruit Pudding menggunakan bahan utama berupa agar-agar dan susu low fat serta bahan tambahan berupa buah sebagai pemberi cita rasa manis untuk produk bread fruit pudding. Pengembangan produk pudding menjadi bread fruit pudding diupayakan dapat menambah wawasan masyarat mengenai pentingnya mempertimbangkan pemakaian gula dan mengubah stigma negatif masyarakat mengenai konsumsi buah dengan cita rasa yang manis. Pengaruh konsumsi pangan berkarbohidrat, termasuk buah, terhadap kadar glukosa darah yang juga disebut respon glikemik, saat ini telah menjadi isu penting, baik untuk pasien diabetes mellitus (diabetesi), pra-diabetes, maupun orang sehat, khususnya dalam memilih jenis, bentuk asupan, dan jumlah karbohidrat ataupun buah yang dikonsumsi (Arif. Et.al 2013).

Menurut Arif. Et.al (2013), sebagian diabetesi tidak mau mengkonsumsi buah karena beranggapan bahwa rasa manis pada buah berhubungan langsung dengan peningkatan kadar gula darah. Respon glikemik buah sebenarnya ditentukan oleh sejumlah faktor, seperti jenis gula yang dikandungnya dan sifatsifat intrinsik yang berkaitan dengan pelepasan gula (sugar release properties) dari buah tersebut. Hal ini ditunjukkan dengan beragamnya nilai (tengah) indeks 
glikemik (IG) buah, yaitu dari 68 hingga 1914. Pemahaman yang komprehensif mengenai hubungan antara kandungan gula/derajat kemanisan buah dan implikasinya terhadap kadar glukosa darah darah sangat diperlukan (Premanath 2011).

Konsep pengembangan produk Bread Fruit Pudding meliputi penggunaan bahan yang telah mempertimbangkan dan mencari sumber pendukung untuk keamanan konsumen dengan keluhan penyakit degeneratif seperti diabetes diantaranya penggunaan roti gandum, pemilihan buah dengan IG rendah dan penggunaan telur. Roti gandum termasuk kedalam karbohidrat kompleks dikarenakan gandum memiliki nilai gizi yang tinggi yang diperlukan oleh tubuh dan didalamnya terdapat mineral, vitamin serta sejumlah fitokimia penting untuk mengatasi resistensi insulin. Penggunaan roti gandung pada produk Bread Fruit Pudding yakni pada produk roti gandum memiliki resistant starch (RS) dalam proses formulasi. Penggunaan RS biasanya diaplikasikan pada produk bakery seperti roti, muffin, dan breakfast cereal (Zhang dan Jin 2011). RS adalah salah satu jenis serat pangan yang mempunyai sifat menguntungkan bagi pencernaan. Salah satunya adalah memperlambat masuknya gula ke dalam aliran darah sehingga akan dihasilkan indeks glikemik yang rendah.

Buah yang digunakan yakni buah yang memiliki kadar indeks glikemi rendah seperti apel, strawberry, jeruk, dan pisang. Kadar nilai IGb/ GI Value dan status IG buah-buah tersebut terdapat pada tabel Nilai dan kelas IG buah segar pada orang dengan gangguan toleransi glukosa (IGT). Nilai dan Kelas IG buah segar pada IGT dapat dilihat pada Tabel 1.

Tabel 1 Nilai dan kelas IG buah segar pada IGT

\begin{tabular}{|c|c|c|}
\hline \multirow[t]{2}{*}{ Nama Buah } & \multicolumn{2}{|c|}{$\begin{array}{l}\text { Orang Dengan Gangguan Toleransi Glukosa/ } \\
\text { Subjects with IGTa }\end{array}$} \\
\hline & Nilai IGb/ GI Value & Kelas IGc/ GI Class \\
\hline Apel/Apple & $36 \pm 3(n=5)$ & rendah/low \\
\hline Strawberry/Strawberry & $40(n=1)$ & rendah/low \\
\hline Jeruk/Orange & $45 \pm 4(n=5)$ & rendah/low \\
\hline Pisang/Banana & $48 \pm 3(n=9)$ & rendah/low \\
\hline
\end{tabular}

Sumber: Atkinson et al. (2008)

meliputi/include diabetes mellitus type 2 , gestational diabetes mellitus

Nilai protein juga menjadi konsep pengembangan produk bread fruits pudding. Makanan dengan kandungan protein dapat menghasilkan energi tanpa memerlukan insulin dalam memprosesnya, kemudian jika mengkonsumsi protein maka tubuh tidak memerintah pankreas untuk memproduksi insulin seperti halnya mengkonsumsi gula. Penggunaan telur dalam produk bread fruits pudding bertujuan menambah nilai gizi pada produk dan menghasilkan tekstur yang lembut pada produk bread fruits pudding.

\section{Bahan-Bahan Pembuatan Produk}

Pengembangan produk pudding mendi bread fruits pudding menggunakan bangan makanan yang aman dijadikan sebagai alternatif produk dessert bagi penderita diabetes mellitus atau bagi konsumen yang ingin mencegah penyakit 
tersebut. Penggunaan bahan pada produk bread fruits pudding telah disesuaikan dengan manfaat dan kegunaan bagi penderita diabetes mellitus. Bahan-bahan produk bread fruits pudding dapat dilihat pada Tabel 2.

Tabel 1 Nama Bahan Produk Bread Fruit Pudding

\begin{tabular}{|c|c|c|}
\hline No & Nama Bahan & Spesifikasi \\
\hline 1. & Roti gandum & $\begin{array}{l}\text { (1) whole wheat bread, (2) tekstur lebih kasar dibandingkan } \\
\text { roti tawar, padat dan berserat. }\end{array}$ \\
\hline 2. & strawberry & $\begin{array}{l}\text { (1) kulit tidak terdapat sayatan dan lubang (2) daun tampak } \\
\text { hijau (3) jarang-jaranya jarak biji pada tekstur. }\end{array}$ \\
\hline 3. & Pisang & $\begin{array}{l}\text { (1) warna kulit kuning mulus, (2) tekstur pisang lembut, } \\
\text { lunak kondisi utuh, (3) Tandannya berwarna hijau. }\end{array}$ \\
\hline 4. & Jeruk & $\begin{array}{l}\text { (1) kulit jeruk oranges merata (2) tidak terdapat robekan } \\
\text { pada kulit dan mengkilap (3) kulit tidak bertekstur tebal. }\end{array}$ \\
\hline 5. & Apel & $\begin{array}{l}\text { (1) kulit apel tidak terdapat sayatan dan lubang (2) tekstur } \\
\text { keras (3) warna apel merah merata. }\end{array}$ \\
\hline 6. & Susu sapi & $\begin{array}{l}\text { (1) kemasan tidak rusak dan mulus atau tidak cacat. (2) } \\
\text { jauh dari tanggal expired. (3) susu kategori low fat. }\end{array}$ \\
\hline 7. & Agar-agar & $\begin{array}{l}\text { (1) kemasan tidak rusak dan mulus atau tidak cacat. (2) } \\
\text { jauh dari tanggal expired. }\end{array}$ \\
\hline 8. & Nutrijel & $\begin{array}{l}\text { (1) kemasan tidak rusak dan mulus atau tidak cacat. (2) } \\
\text { jauh dari tanggal expired. }\end{array}$ \\
\hline 9. & Telur & $\begin{array}{l}\text { (1) tidak terdapat retakan kecil (2) tidak bunyi saat dikocok } \\
\text { (3) jernih pada saat ditropong lampu, miring saat } \\
\text { mengapung }\end{array}$ \\
\hline
\end{tabular}

Keragaman penggunaan, kandungan nutrisi, komponen pangan fungsional dan kualitas penyimpanannya yang tinggi menjadikan gandum sebagai bahan makanan pokok lebih dari sepertiga populasi dunia (Porter 2005). Gandum atau terigu merupakan bahan baku produk makanan olahan seperti: roti, mie, pasta, pizza, biskuit dan lainnya (Bushuk and Rasper 1994). Biji gandum memiliki kandungan gizi yang cukup tinggi, diantaranya karbohidrat $60-80 \%$, protein 10 $20 \%$, lemak $2-2,5 \%$, mineral $4-4,5 \%$ dan sejumlah vitamin lainnya (Pomeranz 1971).

Serat pangan yang sampai saat ini paling banyak digunakan dalam makanan fungsional. Manfaat fisiologis produk yang diberi serat makanan antara lain mengatur fungsi-fungsi usus, mencegah penyakit divertikulosis, konstipasi, mengendalikan kolesterol darah, mengatur kadar gula darah, mencegah obesitas dan mengurangi risiko kanker kolon (Irawan dan Wijaya 2002). Keberadaan serat makanan dalam menu sehari-hari dapat menjaga dan meningkatkan fungsi saluran cerna serta menjaga kesehatan tubuh, terutama untuk menghindari berbagai penyakit degenaratif, seperti obesitas, diabetes melitus, dan penyakit kardiovaskuler (Sardesai 2003).

Produk bread fruits pudding juga menggunakan bahan buah-buahan sebagi penambah cita rasa manis pada produk tersebut. Buah yang digunakan salah satunya strawberry. Strawberry dapat mencegah kanker payudara dan 
leher rahim, dengan kandungan ellagic acid pada buah strawberry, perkembangan kanker dapat dihambat. Buah strawberry memiliki aktivitas antikosidan tinggi karena mengandung quercetin, ellagic, antosianin, dan kaempferol. Fungsi antioksidan strawberry turut disumbang oleh kandungan vitamin $\mathrm{C}$ yang tinggi, yaitu $60 \mathrm{mg}$ per $100 \mathrm{~g}$. Konsumsi delapan buah berukuran sedang dapat mencukupi $160 \%$ kebutuhan vitamin C perhari.

\section{Persiapan}

Persiapan yang dilakukan meliputi penimbangan bahan, pemotongan bahan dan lain-lain dengan manajaman waktu dan urutan yang sistematis untuk mengurangi risiko kegagalan. Ada dua masalah yang perlu diperhatikan pada persiapan bahan makanan, yaitu kontaminasi silang dan waktu bekerja dengan suhu zona berbahaya (Soenardi 2013). Proses persiapan bahan roti dan buah untuk produk bread fruits pudding dapat dilihat pada Gambar 1 .

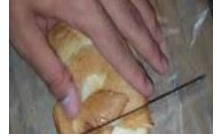

a. Roti dipotong

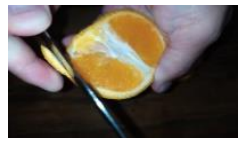

b. kulit jeruk

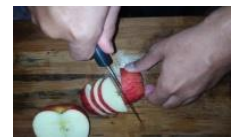

c. apel dipotong

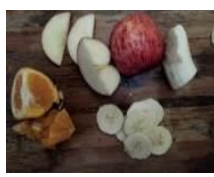

d. semua bahan dipotong

Gambar 1 Proses persiapan bahan roti dan buah Sumber : Dokumentasi pribadi, 2020

Tahap persiapan selanjutnya yakni persiapan telur. Proses Persiapan bahan telur terdapat pada Gambar 2.

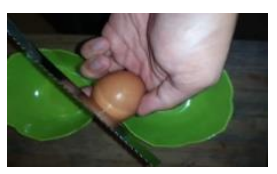

a. telur

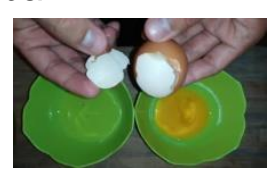

b. telur dipecahkan dan dipisahkan 2 bagian

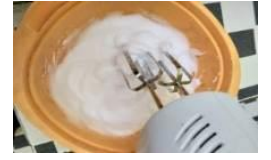

c. putih telur dikocok

Gambar 2 Persiapan bahan telur

Sumber : Dokumentasi pribadi, 2020

Pencucian telur dilakukan untuk membersihkan kotoran yang menempel pada cangkang telur selanjutnya telur dipecahkan dan dipisahkan putih serta kuning telur dalam wadah yang berbeda. Tahap selanjutnya yakni penimbangan susu sapi segar sesuai dengan resep baku. Standar resep adalah resep yang sudah dimodifikasi dan dibakukan untuk menciptakan kualitas/mutu dan porsi makanan yang relatif sama cita rasanya untuk setiap hidangan (Palacio 2010). Standar resep produk bread fruits pudding yaitu100 gram roti gandum; 100 gram strawberry, 100 gram pisang, 300 gram apel, dan 200 gram jeruk; 1 bungkus nutrijel dan 2 bungkus agar-agar; 4 butir telur dan 2 liter susu sapi. Satu resep dapat menghasilkan 10 porsi produk bread fruit pudding. Tahap persiapan selanjutnya yakni persiapan alat dimana jenis alat persiapan harus disesuaikan dengan penggolongan bahan makanannya (Lubis 2013). Alat persiapan yang digunakan dapat dilihat pada Tabel 3. 
Tabel 2 Alat Persiapan Pengolahan Produk

\begin{tabular}{|c|c|c|}
\hline No & Nama alat & Fungsi \\
\hline 1. & Vegetable Knife & Untuk memotong sayuran dan buah \\
\hline 2. & Bread Knife & Untuk memotong roti, sandwich \\
\hline 3. & Ballon Whisk & $\begin{array}{l}\text { Untuk mengocok bahan makanan seperti telur Untuk } \\
\text { mencampur adonan yang terbuat dari tepung dan cairan } \\
\text { (air atau susu) }\end{array}$ \\
\hline 4. & $\begin{array}{l}\text { Timbangan } \\
\text { bahan } \\
\text { makanan }\end{array}$ & $\begin{array}{l}\text { Untuk menimbang bahan makanan sesuai dengan yang } \\
\text { dibutuhkan }\end{array}$ \\
\hline 5. & Gelas Ukur & $\begin{array}{l}\text { Untuk mengukur volume bahan cair seperti air, santan, } \\
\text { kaldu atau susu cair }\end{array}$ \\
\hline 6. & Blender & $\begin{array}{l}\text { Untuk menghaluskan ampas dan sari bahan yang akan } \\
\text { diolah termasuk roti }\end{array}$ \\
\hline 7. & Bowl & $\begin{array}{l}\text { Sebagai wadah serbaguna dalam proses persiapan } \\
\text { misalnya pada saat mencuci, memotong dsb. }\end{array}$ \\
\hline 8. & Cuttingboard & $\begin{array}{l}\text { Sebagai alas pada proses persiapan bahan makanan } \\
\text { misalnya mengiris, memotong, mencincang dsb. }\end{array}$ \\
\hline
\end{tabular}

\section{Pengolahan}

Menurut Lastmi. Et. al (2018), pengolahan atau memasak adalah suatu kegiatan atau proses pemberian panas (application of heat) pada bahan makanan sehingga bahan makanan tersebut dapat dimakan (eatable), lezat di lidah (palatable), aman dimakan (safe to eat), mudah dicerna (digestible), dan berubah penampilannya (change its appearance). Mutu penyelenggaraan makanan yang baik dapat dicapai dengan perhitungan dan kepatuhan terhadap waktu yang tepat dan dipatuhi. Total waktu pengolahan produk yakni 90 menit. Alur produksi bread fruits pudding dapat dilihat pada Gambar 3.

Peralatan pengolahan adalah semua perlengkapan yang diperlukan dalam proses pengolahan makanan. Alat pengolahan produk bread fruits pudding dapat dilihat pada Tabel 4.

Tabel 3 Alat Pengolahan Hidangan

\begin{tabular}{cll}
\hline No & Nama alat & \multicolumn{1}{c}{ Fungsi } \\
\hline 1. & Stove & Untuk memasak dan menghangatkan makanan \\
2. & Sous pan & Untuk merebus cairan hingga titik didih. \\
3. & Ladle & Untuk mengaduk atau mengambil cairan dan \\
& menindahkan cairan masakan \\
4. & Ballon & Untuk mengocok bahan makanan seperti telur Untuk \\
& Whisk & mencampur adonan yang terbuat dari tepung dan cairan \\
\hline
\end{tabular}




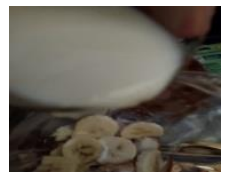

a. Pencampuran bahan dengan susu
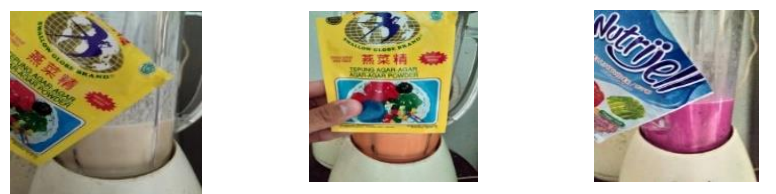

b. Pencampuran bahan dengan Agar-agar dan nutrije
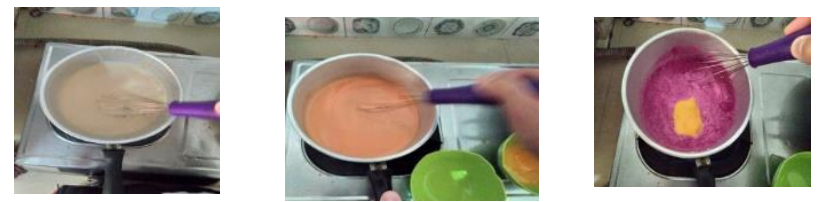

c. Pengolahan dengan teknik boiling
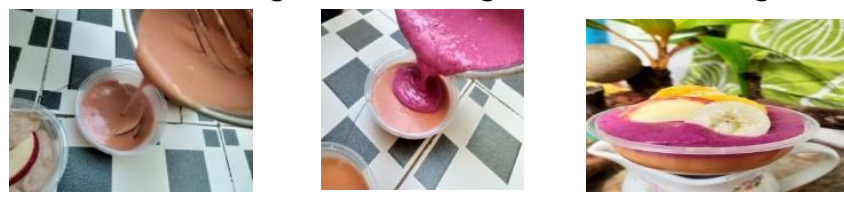

d. finishing produk Bread Fruits Pudding
Bahan dihaluskan dengan menambahkan susu sapi (30 menit)

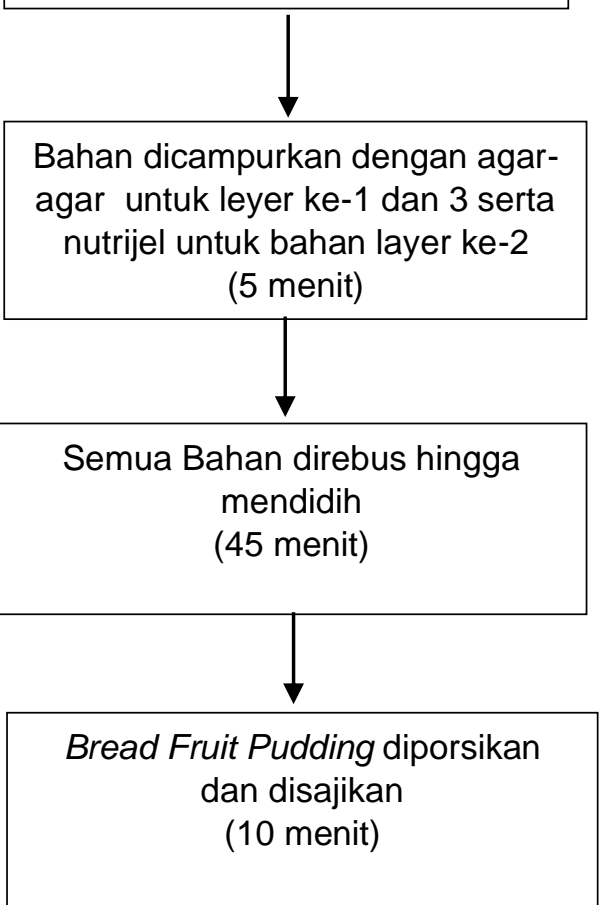

Gambar 3 Alur Produksi Hidangan Bread Fruits Pudding Sumber : Dokumentasi pribadi, 2020

\section{Pemorsian}

Pemorsian produk bread fruit pudding menggunakan satu wadah dessert box, meliputi pertama menuangkan adonan basic layer kemudian dilanjutkan middle layer dan terkahir top layer. Penuangan menggunakan ladle, berat setiap satu tuangan ladle adalah 50 gram sehingga total berat perporsi adalah 150 gram. Produk bread fruits pudding dapat dilihat pada Gambar 4.

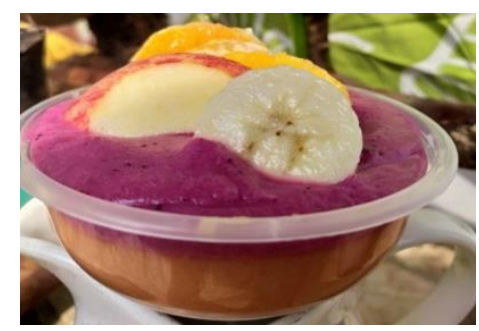

Gambar 4 Produk Bread Fruits Pudding

Sumber : Dokumentasi pribadi, 2020

\section{Kandungan Energi dan Zat Gizi}

Kandungan gizi bread fruits pudding dihitung menggunakan Daftar Komposisi Bahan Makanan Indonesia (DKBM) dan dapat dilihat dari Tabel 5. 
Tabel 5 Kandungan Gizi Produk

\begin{tabular}{|c|c|c|c|c|c|c|c|c|}
\hline \multirow[b]{2}{*}{ No } & \multirow[b]{2}{*}{ Nama Bahan } & \multirow[b]{2}{*}{$\begin{array}{c}\text { Berat } \\
\text { (gram) }\end{array}$} & \multicolumn{6}{|c|}{ Kandungan Gizi } \\
\hline & & & $\begin{array}{c}\text { Energi } \\
\text { (kal) }\end{array}$ & $\begin{array}{c}\text { Protein } \\
\text { (gram) }\end{array}$ & $\begin{array}{l}\text { Lemak } \\
\text { (gram) }\end{array}$ & $\begin{array}{l}\text { Karbo } \\
\text { (gram) }\end{array}$ & $\begin{array}{c}\text { Serat } \\
\text { (gram) }\end{array}$ & $\begin{array}{c}\text { Gula } \\
\text { (gram) }\end{array}$ \\
\hline 1. & Roti gandum & 100 & 247 & 13 & 3,4 & 41 & 7 & 6 \\
\hline 2. & strawberry & 100 & 32 & 0,7 & 0,3 & 8 & 2 & 4,9 \\
\hline 3. & Pisang & 100 & 88 & 1,1 & 0,3 & 23 & 2,6 & 12 \\
\hline 4. & Jeruk & 200 & 94 & 1,8 & 0,2 & 24 & 4,8 & 18 \\
\hline 5. & Apel & 300 & 156 & 0,9 & 0,6 & 42 & 7,3 & 30 \\
\hline 6. & Susu sapi & 2000 & 800 & 60 & 25 & 90 & 0 & 60 \\
\hline 7. & Agar-agar & 14 & 40 & 0 & 0 & 16 & 16 & 0 \\
\hline 8. & Nutrijel & 15 & 40 & 0 & 0 & 12 & 4 & 0 \\
\hline 9. & Telur & 220 & 356 & 28,2 & 25,3 & 1,5 & 0 & 0 \\
\hline \multicolumn{3}{|c|}{ Total 1 resep } & 1853 & 105,7 & 55,1 & 257,5 & 43,7 & 130,9 \\
\hline \multicolumn{3}{|c|}{ Total zat gizi/porsi } & 139 & 8 & 4,2 & 19,4 & 3,3 & 9,9 \\
\hline
\end{tabular}

Kandungan energi dan karbohidrat tertinggi terdapat pada bahan susu sapi dikarenakan penggunaan susu sapi dengan jumlah banyak dibandingkan penggunaan bahan yang lain. Kandungan protein terbesar berasal dari susu sapi dikarenakan penggunaan bahan tersebut dalam jumlah banyak dibandingkan pada bahan yang lain. Protein susu merupakan kelompok molekul yang sangat heterogen yang terdiri dari lima kategori yaitu kasein, protein whey, protein globula lemak susu, enzim dan protein minor lainnya ( $\mathrm{Ng}$-KwaiHang 2003). Protein utama adalah kasein dan protein whey. Protein susu bukan hanya berfungsi sebagai asupan kecukupan gizi, tetapi juga fungsi lainnya. Susu juga mengandung berbagai senyawa bioaktif dengan sifat khusus yang terkait dengan perkembangan, pertumbuhan dan kelangsungan hidup bayi (Schanbacher, et.al. 1998), salah satunya adalah sebagai antimikrobia. Protein antimikroba utama dalam susu adalah imunoglobulin, laktoferin, laktoperoksidase dan lisozim (Tanaka 2007).

Bahan dengan kandungan lemak terbesar adalah telur dikarenakan telur mengandung $60 \%$ lipoprotein dan merupakan senyawa kompleks dari lipid netral, fosfolipid dan protein. Selain itu lipoprotein kuning telur terdiri atas $85 \%$ Lemak dan $15 \%$ protein . Lemak dari lipoprotein terdiri atas $20 \%$ fosfolipid (lecithinm, fosfatidil serin), 60\% Lemak netral (trigeliserida) dan 5\% kolesterol (Larni,et al. 1996). Kuning telur mengandung lebih kurang 33\% padatan, sebagian besar lipoprotein yang kaya dengan trigliserida, lipovitellin, clan fosvitin, sedangkan sebagian kecil immunoglobulin, serum albumen protein pengikat protein . Lebih dari $95 \%$ kolesterol dari kuning telur bergabung dalam lipoprotein yang kaya trigliserida, sedangkan sisanya mengelilingi lipovitellin, sebagai protein atau lemak kompleks yang terdiri atas kurang $20 \%$ lernak dan $4 \%$ kolesterol .

Kandungan terbesar susu adalah air dan lemak. Setiap porsi lemak susu mengandung vitamin yang hanya larut dalam lemak yaitu vitamin $A, D, E$ dan $\mathrm{K}$. Air susu mengandung berbagai macam tipe protein, yang dapat dikelompokkan menjadi 2 macam, yaitu kasein $(80 \%)$ dan laktoglobulin (20\%). Protein dalam susu merupakan prioritas utama yang diinginkan (Beata, et al. 2008; Daniela, et 
al. 2008). Kandungan gula terbesar berasal dari susu sapi dikarenakan terdapat kandungan laktosa atau gula susu. Laktosa terdiri dari molekul glukosa dan molekul galaktosa. Laktosa hanya ditemukan pada susu mamalia. Susu sapi mengandung rata-rata 4,7 gram laktosa per 100 gram (Schaafsma 2008).

Kandungan serat terbesar berasal dari bahan agar-agar berbahan rumput laut. Menurut Astawan, et.al. (2004), secara kimia rumput laut terdiri dari abu $29,97 \%$; protein $5,91 \%$; lemak $0,28 \%$; karbohidrat $63,84 \%$; serat pangan total $78,94 \%$ dan iodium $282,93 \%$. Pada produk bread fruits pudding penggunaan bahan yang tinggi serat bertujuan untuk menyerap air dan mengikat glukosa sehingga mengurangi ketersediaan glukosa. Diet cukup serat juga menyebabkan terjadinya kompleks karbohidrat dan serat, sehingga daya cerna karbohidrat berkurang. Keadaan tersebut mampu meredam kenaikan glukosa darah dan menjadikannya tetap terkontrol.

Penyakit diabetes diantaranya dicirikan dengan terjadinya hiperglikemik kronis yang menyebabkan sejumlah komplikasi vascular. Salah satu strategi efektif untuk mencegah hiperglikemik yaitu dengan menghambat penyerapan glukosa di usus kecil. Penelitian sebelumnya melaporkan bahwa sejumlah polifenol tanaman mempunyai kemampuan menghambat penyerapan glukosa di usus kecil, sehingga diduga dapat membantu menurunkan respon glikemik pangan yang berasal dari tanaman (Johnston, et.al 2005).

Semua bahan yang digunakan produk bread fruit pudding mengandung zat gizi makro dan mikro yang baik bagi tubuh serta menggunakan pemanis alami dari buah segar untuk alternatif dessert bagi penderita diabetes mellitus. Produk bread fruits pudding diupayakan untuk memenuhi standar kebutuhan hidangan dessert atau makanan selingan bagi penderita diabetes milletus. Diet diabetes dikelompokkan menjadi diet 1100 kalori sampai 2500 Kalori (Almatsier 2004). Makanan selingan/dessert berkontribusi 10-15\% dari kebutuhan energi sehari. Analisa Kontribusi Energi Produk terhadap Diet Diabetes Milletus dapat dilihat pada Tabel 6.

Tabel 6 Analisa Kontribusi Energi Produk terhadap Diet Diabetes Milletus

\begin{tabular}{ccc}
\hline No & Jenis Diet Diabetes Milletus & Kontribusi Energi Produk (10-15\%) \\
\hline 1. & Diet DM 1100 Kalori & $12,6 \%$ \\
2. & Diet DM 1300 Kalori & $10,7 \%$ \\
3. & Diet DM 1500 Kalori & $9,3 \%$ \\
4. & Diet DM 1700 Kalori & $8,2 \%$ \\
5. & Diet DM 1900 Kalori & $7,3 \%$ \\
6. & Diet DM 2100 Kalori & $6,6 \%$ \\
7. & Diet DM 2300 Kalori & $6 \%$ \\
8. & Diet DM 2500 Kalori & $5,6 \%$ \\
\hline
\end{tabular}

Berdasarkan Tabel 6 diketahui bahwa 150 gram produk dapat menyumbang energi sebesar 10.7 - $12.6 \%$ untuk diet DM $1100-1300$ Kalori sehingga memenuhi ketentuan sebesar 10 - 15\% tetapi untuk diet DM 1500 2500 Kalori pada produk bread fruits pudding belum memenuhi ketentuan 
sehingga untuk diet DM 1500 - 2500 Kalori perlu ditambahkan makanan pendamping produk bread fruits pudding.

\section{Uji Kesukaan}

Uji kesukaan menurut Sofiah dan Achsyar (2008) merupakan uji dimana panelis diminta memberi tanggapan secara pribadi tentang kesukaan atau ketidaksukaan beserta tingkatannya. Produk yang diujikan kepada panelis adalah produk hasil uji coba ke-8. Hasil uji kesukaan terhadap penampilan menunjukkan $78 \%$ suka dan $22 \%$ sangat suka. Uji kesukaan terhadap penampilan menunjukkan hasil yang bagus karena tidak ada panelis menunjukkan respon tidak suka atau kurang suka.

Penampilan produk bread fruits pudding ditunjang dari warna produk itu sendiri yaitu ada tiga lapisan pudding dengan warna yang berbeda. Warna yang diperoleh dari produk Bread Fruits Pudding yakni warna coklat pada basic layer (campuran roti gandum dan pisang); dua warna pada middle layer yakni warna putih (campuran putih telur yang telah dikocok dan larutan pudding) pada lapisan setelah warna coklat dan warna merah (campuran buah strawberry, buah naga, buah apel dan larutan pudding) pada lapisan setelah warna putih; warna orange pada top layer (campuran buah jeruk, putih telur dan larutan cairan pudding), sehingga dari empat warna yang diperoleh menjadi daya tarik dari penampilan produk bread fruit pudding.

Berdasarkan hasil uji kesukaan terhadap porsi diketahui $12 \%$ kurang suka dan $78 \%$ sangat suka. Hasil ini menunjukkan bahwa besar porsi bread fruit pudding (150 gram) telah sesuai dengan harapan panelis sehingga perhitungan sudah cocok dengan harapan konsumen. Hasil uji kesukaan terhadap rasa diketahui $22 \%$ sangat suka, $56 \%$ suka, dan $22 \%$ kurang suka. Rasa kurang suka dipengaruhi faktor rasa dari buah pisang yang dicampur dengan roti gandum.

Hasil uji kesukaan terhadap tekstur diketahui $89 \%$ suka dan $11 \%$ kurang suka. Hasil ini menunjukkan disukai oleh panelis dikarenakan ada variasi tiga lapisan mulai dari hard to soft texture. Basic layer memiliki tekstur padat dan keras dikarenakan berasal dari bahan roti, kemudian pada middle layer memiliki dua perbedaan dari segi tekstur yakni high soft texture yang diperoleh dari lapisan warna putih dan medium soft texture dari lapisan warna merah. Top layer memiliki tekstur medium soft texture diperoleh lapisan warna orange.

\section{SIMPULAN}

Bread fruit pudding merupakan alternatif hidangan dessert /snack manis untuk penderita diabetes mellitus dengan tekstur yang lunak dan pemanis alami dari buah dengan IG rendah yaitu strawberry, pisang, jeruk dan apel. Alur produksi hidangan bread fruits pudding terdiri dari tiga tahapan (persiapan, pengolahan, pemorsian). Berat per porsi sebesar 150 gram. Hasil uji organoleptik diperoleh bahwa produk bread fruits pudding disukai baik dari penampilan $(100 \%)$, porsi $(78 \%)$, rasa $(78 \%)$ maupun tekstur $(89 \%)$. Kandungan gizi per 150 gram bread fruit pudding mengandung energi 139 Kalori; protein 8 gram; 
lemak 4,2 gram; karbohidrat 19,4 gram; serat 3,3 gram dan gula alami sebesar 9,9 gram.

\section{SARAN}

Produk bread fruit pudding dari hasil uji kesukaan menunjukkan hasil yang positif dimana dari data yang diperoleh tidak ada respon dari panelis yang menunjukkan tidak suka terhadapat produk tersebut, akan tetapi perlu perbaikan ulang mengenai rasa terhadap produk bread fruit pudding supaya produk tersebut sangat diterima dan digemari oleh semua kalangan panelis baik terlatih maupun tidak terlatih. Selain itu perlu dilakukan penelitian lebih lanjut terkait nilai IG dari produk.

\section{DAFTAR PUSTAKA}

Almatsier,S. 2004. Penuntun Diet Edisi Baru. Jakarta: Gramedia Pustaka Utama. Arif, A.B, Agus, B dan Hoerudin. 2013. Nilai Indeks Glikemik Produk Pangan Dan Faktor-Faktor Yang Memengaruhinya. J. Litbang Pert. Vol. 32: 91-99

Arini, W. 2015. "Kadar Antioksidan dan Uji Organoleptik Puding Kulit Buah Manggis dengan Penambahan Buah Kurma Sebagai Perasa manis Alami”. Skripsi. Universitas Muhammadiyah Swakarta.

Astawan, M., S. Koswara., dan F. Herdiani. 2004. Pemanfaatan rumput laut (Eucheuma cottonii) untuk meningkatkan kadar iodium dan serat pangan pada selai dan dodol. Jurnal Teknologi dan Industri Pangan XV (1) : 61-69

Atkinson, F.S., K. Foster-Powell, and J.C. Brand Miller. 2008. International tables of glycemic index and glycemic load values: 2008. Diabetes Care 31: 2281-2283

Beata, S., Wojciech, N. \& Ewa, W. 2008. Relations between kappa-casein polymorphism (CSN3) and milk performance traits in heifer cows. Journal of Central European Agriculture. 9:641-644.

Brand, J.C., S. Calaguiri, S. Crossman, A. Allan, D.C.K. Roberts, and A.S. Truswell, Low glycemic index foods improve long-term glycemic control in NIDDM. Diabetes Care.

Bushuk, W., and Rasper, V.F. 1994. Wheat: Production, Properties, and Quality. Chapman \& Hall. United Kingdom.

Daniela, I., Aurelia, S., Anuta, M., Claudia, S. \& Vintila, I. 2008. Genetic polymorphism at the $\beta$-lactoglobulin locus in a dairy herd of Romanian Spotted and Brown of Maramures breeds. Zoo. Biotech. 41:104-107.

Ekawatiningsih. P, et al. 2008. Restoran Jilid 2. Jakarta: Direktorat Pembinaan Sekolah Menengah Kejuruan.

Emanath M, Gowdappa HM, Mahesh M, Babu MS. 2011. A study of glycemic index of ten Indian fruits by an alternate approach. E-Internasional Scientific Research Journal. 2011; 3(1):11-18.

Ikram EHK, Eng KH, Jalil AMM, Ismail A, Idris S, Azlan A, Nazri HSM, Diton NAM, Mokhtar RAM. 2009. Antioxidant capacity and total phenolic content of Malaysian underutilized fruits. Journal of Food Composition and Analysis. 2009; 22(5):388-393. 
Indrie, A., Qantah, Sarjana. 2009. Penerapan Standar Penggunaan Pemanis Buatan Pada Produk Pangan. Jurnal Standardisasi Vol. 11, No. 1 Tahun 2009: 46 - 56

Irawan, D. and C.H. Wijaya. 2002. The potencies of natural foodadditives as bioactive ingredients. Prosiding Kolokium Nasional Teknologi Pangan. Semarang. 24 Juni 2002.

Jenkins DJA, Wolever TMS, Taylor $\mathrm{RH}$, Barker $\mathrm{H}$, Fielden $\mathrm{H}$, Baldwin JM, Bowling AC, Newman HC, Jenkins AL, Goff DV. 1981. Glycemic index of foods: a physiological basis for carbohydrate exchange. American Journal of Clinical Nutrition. 1981; 34:362-366.

Jenkins, D.J.A., C.W.C. Kendall, L.S.A. Augustin, S. Franceschi, M. Hamidi, A. Marchie, A.L. Jenkins, and M. Axelsen. 2002. Glycemic index: overview of implications in health and disease. Am. J. Clin. Nutr. 76(Suppl.): 266S-273S.

Johnston, K., P. Sharp, M. Clifford, and L. Morgan. 2005. Dietary polyphenols decrease glucose uptake by human intestinal Caco-2 cells. FEBS Letters. 2005. 579(7):1653-1657.

Kotler, P and Armstrong. 2009. Manajemen Pemasaran, Edisi 13, Jilid 1 dan 2, Erlangga, Jakarta.

Kemenkes RI. 2014. Peraturan Menteri Kesehatan Republik Indonesia no 41 tahun 2014 tentang Pedoman Gizi Seimbang. Kementerian Kesehatan Indonesia Republik Indonesia, Jakarta

Latsmi, W., Irfanny, Z.A., Zul. A. 2018. Sistem Manajemen Penyelenggaraan Makanan Institusi. Kementerian Kesehatan Republik Indonesia, Jakarta.

Larni:, KS, Gohl Y. K, Jump Sen J.L, Ryan E.A, Chow P, Dandinin MT. 1996. Normal subjects consuming physiological level pf $18: 3(n-3)$ and 20:5 from flaxseed or fish oils have characteristic differences in plasma lipid and lipoprotein fatty acid level. Journal Nutrition : 126.

Lubis, C. 2013. Boga Dasar. Buku Ajar Kelas 10 SMK. Direktorat Pembinaan SMK. Cetakan 1.Jakarta.

$\mathrm{Ng}$-Kwai-Hang KF. 2003. Milk proteins-heterogeneity, fractionation and isolation. In: Roginski H, Fuquay JW, Fox PF, editors, Encyclopedia of Dairy Sciences. London: Academic Press. pp. 1881- 1894.

Palacio J.P, dan Monica T. 2010. Introduction To Food Service. 11 th Edition. Pearson Education Inc.

Pomeranz, Y. 1971. Composition and functionality of wheat flour components dalam Y. Pomeranz. Wheat Chemistry and Technology. The AACC. Ind., St. Paul.

Porter J.R. 2005. Rising temperatures are likely to reduce crop yields. Nature 436:174.

Premanath M, Gowdappa HM, Mahesh M, Babu MS. 2011. A study of glycemic index of ten Indian fruits by an alternate approach. E-Internasional Scientific Research Journal. 2011; 3(1):11-18.

Sari, D. N. I. 2014. "Pembuatan Puding Waluh (Cucurbita Moschata) dengan Pemanis Alami Daun Stevia (Stevia Rebaudiana) Untuk Kudapan Penderita Diabetes". Skripsi. Universitas Muhammadiyah Surakarta. 
Sardesai, V. 2003. Introduction to clinical nutrition. Marcel Dekkerlnc., New York. p. 339- 354.

Schaafsma, G. 2008. Lactose and lactose derivatives as bioactive ingredients in human nutrition. International Dairy Journal, 2008, Vol. 18: 458-465.

Schanbacher FL, Talhouk RS, Murray FA, Gherman LI, \& Willett LB. 1998. Milkborne bioactive peptides. Int Dairy J 8: 393-403.

Soenardi, T, et al. 2013. Teori Dasar Kuliner: Teori Dasar Memasak untuk Siswa, Peminat Dan Calon Profesional. Jakarta (ID): Gramedia Pustaka Utama.

Sofiah, B. D., Achyar, T. S. 2008. Buku Ajar Kuliah Penilaian Indra (Cetakan ke1) Jatinangor: Universitas Padjadjaran.

Tanaka T. 2007. Antimicrobial activity of lactoferrin and lactoperoxidase in milk. In: Ling JR, editor, Dietary Proteins Research Trends. New York: Nova Science Publishers Inc. pp. 101-115.

Ulrich, Karl T., dan Steven D., Eppinger., 2001. Perancangan dan Pengembangan Produk, Edisi 1, Salemba Teknika, Jakarta.

World Health Organization (WHO). 2000. Pencegahan Diabetes Mellitus. Hipokrates. Jakarta.

Zhang, H., Jin, Z., 2011. Preparation of products rich in resistant starch from maize starch by an enzymatic method. Carbohydrate Polymers 86, 16101614 